\title{
Eksplorasi sumber air tanah bawah perbukitan kapur (karst) menggunakan metode geolistrik resistivitas konfigurasi Schlumberger di desa Darmakradenan kecamatan Ajibarang kabupaten Banyumas
}

\author{
Hastani Ratsanjani dan Sehah* \\ Program Studi Fisika, Fakultas MIPA, Universitas Jenderal Soedirman \\ Jalan Dr. Suparno No.61 Grendeng Purwokerto Jawa Tengah \\ *email:sehah@unsoed.ac.id
}

\begin{abstract}
Abstrak - Penelitian menggunakan metode geolistrik resisitivitas telah dilakukan untuk mengetahui struktur batuan bawah permukaan serta potensi air tanah di Desa Darmakradenan Kecamatan Ajibarang Kabupaten Banyumas. Konfigurasi yang digunakan pada metode ini adalah konfigurasi Schlumberger sebanyak lima titik VES dengan panjang lintasan masing-masing $200 \mathrm{~m}$. Hasil pemodelan secara inversi telah menghasilkan log resistivitas yang terdiri atas enam lapisan batuan bawah permukaan. Lapisan batuan tersebut diinterpretasi sebagai tanah penutup dengan nilai resistivitas sebesar 206.8 - $1204.92 \mathrm{ohm} \mathrm{m}$, batukapur dengan nilai resistivitas sebesar 767.51 - $1563.65 \mathrm{ohm} \mathrm{m}$, kerikil dan pasir dengan nilai resistivitas sebesar $270.84 \mathrm{ohm} \mathrm{m}$, lempung dengan nilai resistivitas sebesar 319.39 - $473.97 \mathrm{ohm} \mathrm{m}$, batupasir gampingan dengan nilai resistivitas sebesar $17.22 \mathrm{ohm} \mathrm{m}$, dan napal dengan nilai resistivitas sebesar 814.17 - $982.94 \mathrm{ohm} \mathrm{m}$. Potensi sumber air tanah diperkirakan hanya terdapat di titik S-L1 dan S-L2 yang merupakan lapisan batupasir gampingan dengan nilai resitivitas $17.22-47.02 \mathrm{ohm}$ m pada kedalaman $11.80-70.00 \mathrm{~m}$ dan diinterpretasi sebagai akuifer dangkal.
\end{abstract}

Kata kunci: geolistrik resistivitas, sumber air tanah, pegunungan kapur, Desa Darmakradenan

\begin{abstract}
Research using the geoelectric resisitivity method has been conducted to determine the subsurface rock structure and the potential for groundwater in Darmakradenan Village, Ajibarang District, Banyumas Regency. The configuration used in this method is the Schlumberger configuration of five VES points with a tracks length of $200 \mathrm{~m}$ for each track. The results of inversion modeling have produced a resistivity log consisting of six subsurface rock layers. The rock layers are interpreted as top soil with a resistivity value of $206.8-1204.92 \mathrm{ohm} \mathrm{m}$, limestone with a resistivity value of $767.51-1563.65 \mathrm{ohm} \mathrm{m}$, sand and gravel with a resistivity value of $270.84 \mathrm{ohm} \mathrm{m}$, clay with a resistivity value of $319.39-473.97 \mathrm{ohm} \mathrm{m}$, limestone sandstones with a resistivity value of $17.22 \mathrm{ohm} \mathrm{m}$, and marl with a resistivity value of 814.17 - $982.94 \mathrm{ohm} \mathrm{m}$. Groundwater sources potential are estimated to only exist at points of S-L1 and S-L2 which are limestone sandstone layers with a resistivity value of $17.22-47.02 \mathrm{ohm} m$ at a depth of $11.80-70.00 \mathrm{~m}$ and interpreted as shallow aquifer.
\end{abstract}

Key words: geoelectric resistivity, groundwater sources, karst mountains, Darmakradenan Village

\section{PENDAHULUAN}

Air permukaan dan air tanah merupakan sumber air utama yang digunakan oleh masyarakat untuk memenuhi berbagai kebutuhan hidup. Air tanah terdapat di dalam lapisan batuan yang mengandung air secara ekonomis, yang disebut akuifer [1]. Kedalaman air tanah di suatu daerah tidak sama dengan daerah lainnya, tergantung ketebalan lapisan penutup dan posisi lapisan akuifernya [2]. Untuk mendapatkan informasi tentang susunan lapisan batuan bawah permukaan termasuk lapisan akuifer, maka kegiatan penyelidikan bisa dilakukan, agar keberadaan akuifer, kedalaman dan ketebalannya dapat diindentifikasi dengan mudah. Beberapa teknik penyelidikan keberadaan dan potensi air tanah yang bisa dilakukan antara lain adalah metode geologi, magnetik, gravitasi, seismik dan metode geolistrik. Diantara metode-metode tersebut, metode geolistrik merupakan metode yang banyak sekali digunakan untuk eksplorasi air tanah dimana hasilnya cukup baik sebab metode ini memiliki beberapa keunggulan daripada metode yang lain [3]. Keunggalan metode ini adalah peralatannya relatif murah dibandingkan dengan metode lain, biaya survei relatif murah, waktu yang dibutuhkan relatif cepat, dan bisa diterapkan untuk berbagai bidang, seperti bidang geoteknik, pertambangan, perminyakan, hidrologi dan lain-lain [4].

Geolistrik merupakan salah satu metode survei geofisika yang bertujuan untuk 
mengidentifikasi sifat-sifat kelistrikan batuan bawah permukaan dengan cara menginjeksikan arus listrik ke dalam tanah. Geolistrik merupakan metode survei geofisika aktif, karena arus listrik ini berasal dari luar sistem [5]. Tujuan survei geolistrik adalah untuk memperoleh nilai resistivitas batuan. Resistivitas adalah besaran fisika yang menunjukkan tingkat hambatan benda terhadap arus listrik. Batuan yang memiliki nilai resistivitas besar, menunjukkan bahwa batuan tersebut sulit dialiri arus listrik. Resistivitas batuan dapat diukur dengan menginjeksikan arus listrik ke dalam tanah melalui dua elektrode di permukaan tanah dan mengukur beda potensial yang muncul di permukaan yang sama melalui dua elektroda pada titik yang lain [6]. Hasil pengukuran geolistrik-resistivitas dapat berupa peta sebaran resistivitas batuan baik secara mapping (horisontal) maupun sounding (vertikal). Penerapan pengukuran geolistrik secara mapping maupun sounding disesuaikan dengan kebutuhan dilakukannya akuisisi data resistivitas serta jenis konfigurasi yang digunakan [7].

Darmakradenan merupakan salah satu desa di Kecamatan Ajibarang, Kabupaten Banyumas yang mempunyai potensi bahan tambang batukapur terbesar se-kabupaten. Di wilayah itu terdapat gugusan perbukitan batukapur yang memanjang kurang lebih empat kilometer melewati beberapa kecamatan, seperti Ajibarang, Gumelar, dan Pekuncen [8]. Berdasarkan data dari Dinas Pertambangan Kabupaten Banyumas jumlah cadangan batukapur (limestone) yang dapat dieksploitasi di daerah tersebut dapat mencapai 442.181.173 ton [9]. Jumlah tersebut hanya cadangan di Desa Darmakradenan, adapun di desa dan kecamatan lain tidak diperhitungkan [9]. Dengan demikian jumlah cadangan kapur di perbukitan tersebut jauh lebih besar daripada yang disampaikan Pemerintah Daerah. Awalnya penambangan batukapur masih dilakukan secara manual menggunakan cangkul, linggis, dan lain-lain, namun sekarang telah mengalami kemajuan dengan melibatkan alat berat. Apalagi saat ini telah berdiri pabrik semen yang juga menambang material batukapur di gugusan perbukitan kapur tersebut. Meskipun dampak positifnya sangat besar, namun kegiatan ini dikhawatirkan berdampak terhadap menurunnya fungsi akuifer air tanah, sehingga masyarakat mengalami kesulitan untuk mendapatkan sumber air bersih. Oleh sebab itu, survei resistivitas yang bertujuan untuk mengeksplorasi sumber-sumber air tanah (lapisan akuifer) perlu dilakukan di kawasan perbukitan kapur (karst) tersebut.

\section{LANDASAN TEORI}

\section{A. Metode Geolistrik Resistivitas}

Geolistrik merupakan salah satu metoda geofisika untuk mengetahui perubahan resistivitas lapisan batuan di bawah permukaan tanah dengan cara mengalirkan arus listrik DC (Direct Current) yang mempunyai tegangan tinggi ke dalam tanah. Injeksi arus listrik menggunakan 2 buah elektroda $\mathrm{C}_{1}$ dan $\mathrm{C}_{2}$ yang ditancapkan ke dalam tanah pada jarak tertentu. Semakin panjang jarak elektroda arus, akan mengakibatkan arus listrik menembus lapisan batuan lebih dalam. Dengan adanya aliran arus listrik tersebut, maka akan menimbulkan polarisasi listrik di dalam tanah. Beda potensial yang terjadi akibat polarisasi listrik pada permukaan ini diukur melalui dua buah elektroda potensial di titik $\mathrm{P}_{1}$ dan $\mathrm{P}_{2}$. Apabila jarak bentangan elektroda arus diubah menjadi lebih besar, maka beda potensial yang terjadi juga ikut berubah sesuai dengan jenis batuan yang terinjeksi oleh arus listrik pada kedalaman tertentu [10]. Skema pengukuran resistivitas di dalam survei geolistrik dapat dilihat pada

Gambar 1.

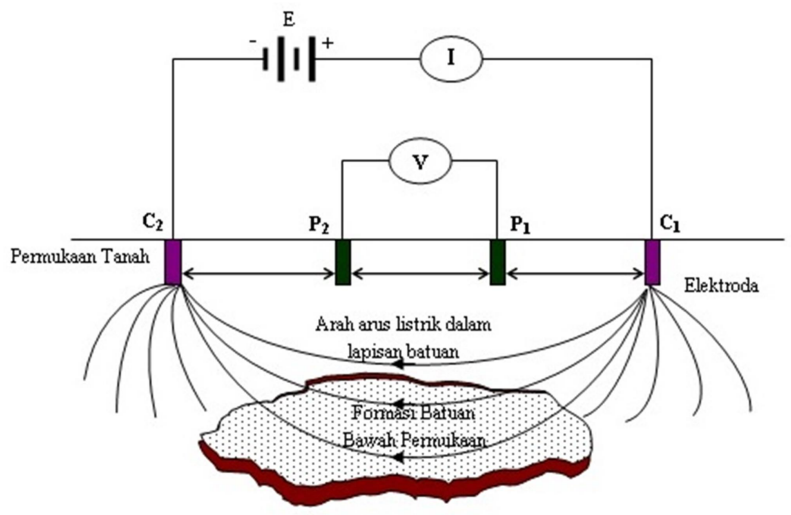

Gambar 1. Skema pengukuran resistivitas batuan bawah permukaan di dalam survei geolistrik [11].

Setelah diperoleh nilai arus $(I)$ dan beda potensial $(\Delta V)$, maka resistivitas semu (apparent resistivity) untuk masing-masing lapisan batuan bisa dihitung dengan persamaan [12]:

$$
\rho_{a}=K \frac{\Delta V}{I}
$$

di mana $K$ adalah faktor geometri. Besarnya faktor geometri tergantung dari konfigurasi elektroda yang digunakan dalam pengukuran geolistrik ini. Untuk konfigurasi Schlumberger, susunan dan jarak bentangan antar elektroda 
didesain seperti terlihat pada Gambar 2, dengan nilai faktor geometri dapat dirumuskan sebagai berikut [12]:

$$
K_{S c h}=\frac{2 \pi}{\left(\frac{1}{A M}-\frac{1}{M B}\right)-\left(\frac{1}{A N}-\frac{1}{N B}\right)}=\pi\left(\frac{a^{2}-b^{2}}{2 b}\right)
$$

Resistivitas semu terjadi karena bumi tersusun atas lapisan-lapisan batuan dengan nilai $\rho$ yang berbeda-beda, sehingga potensial yang terukur dipengaruhi lapisan-lapisan tersebut. Dengan demikian nilai resistivitas yang terukur bukan nilai resistivitas untuk sebuah lapisan saja, terutama untuk spasi elektroda yang lebar [13]. Nilai resistivitas beberapa jenis batuan dan mineral ditunjukkan pada Tabel 1.

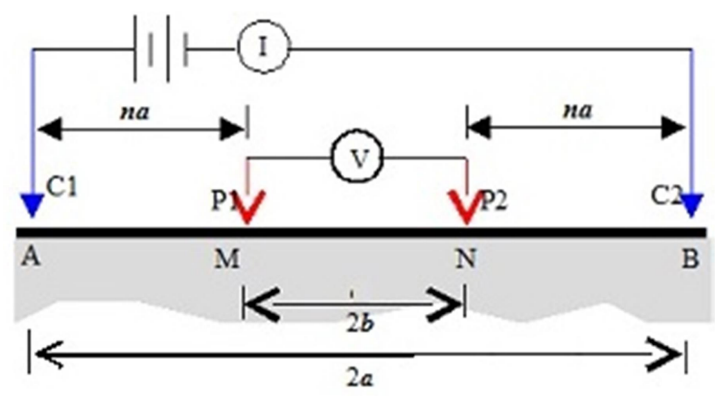

Gambar 2. Skema peralatan pengukuran teknik geolistrik dengan konfigurasi Schlumberger [11].

Tabel 1. Tabel resistivitas batuan dan material lain [12]

\begin{tabular}{ll}
\hline Material & Resistivitas $(\Omega \mathrm{m})$ \\
\hline Udara & $\sim$ \\
Kuarsa & $500-800.000$ \\
Garam batu & $30-1 \times 10^{13}$ \\
Granit & $200-10.000$ \\
Andesit & $1.700-45.000$ \\
Basaltik & $200-100.000$ \\
Gamping & $500-10.000$ \\
Batupasir & $200-8.000$ \\
Pasir & $1-1.000$ \\
Lempung & $1-100$ \\
Air tanah & $0,5-300$ \\
Air asin & 0,2 \\
Kerikil kering & $600-10.000$ \\
Alluvium & $10-800$ \\
Kerikil & $100-600$ \\
\hline
\end{tabular}

Konfigurasi Schlumberger pada survei geolistrik memiliki kelebihan dan kekurangan. Kelebihannya adalah dapat untuk mendeteksi adanya non-homogenitas lapisan batuan di dekat dan bawah permukaan, yaitu dengan membandingkan nilai resistivitas semu ketika jarak bentangan elektroda potensial MN/2 berubah. Tetapi kelemahan konfigurasi Schlumberger adalah pembacaan beda potensial pada elektroda MN lebih kecil terutama pada saat jarak elektroda $\mathrm{AB}$ yang relatif jauh [13]. Konfigurasi Schlumberger biasanya digunakan untuk Sounding, yaitu pengambilan data resistivitas batuan bawah permukaan yang difokuskan secara vertikal, sehingga sering disebut teknik Vertical Electrical Sounding (VES).

\section{B. Akuifer Air Tanah}

Akuifer merupakan formasi geologi yang jenuh sehingga dapat dijadikan pemasok air dalam jumlah yang ekonomis (jumlahnya cukup untuk suatu keperluan seperti domestik, pertanian, peternakan, industri, dan lainnya). Oleh sebab itu formasi ini harus mampu menyimpan dan melewatkan air. Akuifer juga diartikan suatu satuan geologi yang jenuh dan dapat memasok air ke dalam sumur atau mata air sehingga dapat digunakan sebagai sumber air manusia dan makhluk hidup lainnya. Akuifer disebut juga water bearing formation atau formasi yang mengandung air, dan disebut juga sebagai groundwater reservoir atau waduk air tanah. Untuk dapat berfungsi sebagai akuifer, suatu batuan haruslah berpori atau berongga yang berkaitan satu dengan lain, sehingga dapat menyimpan dan meloloskan air tanah untuk bergerak dari rongga ke rongga lain dalam lapisan batuan.

Air tanah adalah air yang tersimpan di bawah permukaan tanah, dimana pergerakannya mengikuti prinsip dasar fisika khususnya fluida [14]. Keberadaannya di permukaan bumi sangat tergantung dari ada tidaknya lapisan akuifer. Secara alami tidak seluruh batuan dapat bertindak sebagai akuifer, mengingat akuifer sangat bergantung terhadap ruang antar butiran (pori-pori batuan) dan permeabilitasnya. Batupasir atau batuan sedimen yang tersusun atas butir kasar memiliki persyaratan untuk itu, terutama beberapa batuan yang belum terkompakan (unconsolidated rock). karena itu juga sangat tergantung pada umur batuan. Batuan-batuan yang berumur tua biasanya telah mengalami kompaksi atau pemadatan dan sementasi sehingga ruang antar butiran menjadi rapat dan termampatkan. Hal ini menyebabkan batuan ini tidak dapat menampung dan meloloskan air dalam jumlah banyak dan bahkan cenderung kedap (impermeable). Batuan seperti ini memiliki permeablitas dan porositasnya kecil, demikian juga halnya batuan beku dan batuan metamorf. Pada zona-zona 
seperti ini sangat sulit diharapkannya ada air tanah, kecuali pada batuan-batuan tersebut banyak ditemui rekahan yang sering disebut sebagai akuifer rekahan (fracture aquifer) [15]. Contoh lapisan akuifer ditunjukkan pada

Gambar 3.

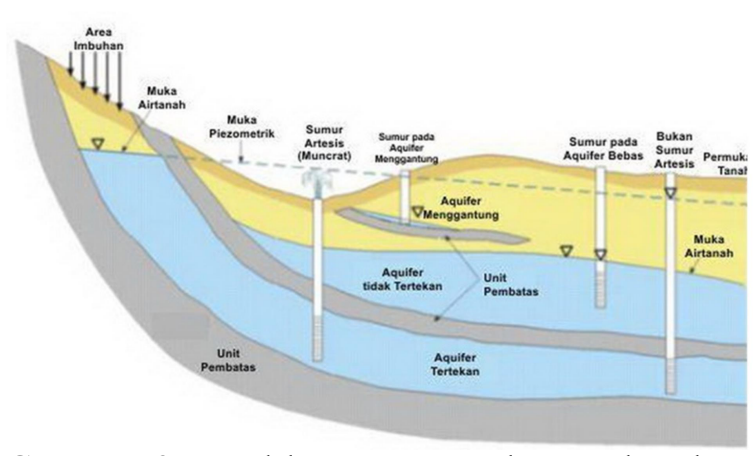

Gambar 3. Model penampang batuan bawah permukaan yang memperlihatkan lapisan akuifer air tanah [14].

\section{METODE PENELITIAN}

\section{A. Persiapan}

Pada tahap persiapan ini, kegiatan yang dilakukan adalah melakukan survei geologi pendahuluan di lokasi penelitian, menyiapkan peralatan resistivitymeter dan kelengkapannya, membentuk tim penelitian, khususunya tim akuisisi data di lapangan, mempelajari peta topografi dan peta geologi serta hasil survei pendahuluan untuk menentukan letak titik-titik sounding survei geolistrik di lokasi penelitian. Peralatan Naniura Resistivity-meter yang digunakan di dalam akuisisi data resistivitas ditunjukkan pada Gambar 4,

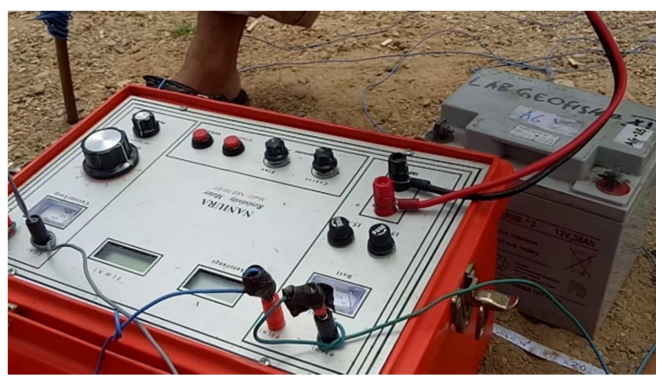

Gambar 4. Peralatan Naniura Resistivity meter yang digunakan dalam akuisisi data resistivitas.

\section{B. Pelaksaaan}

Teknik akuisisi data resistivitas yang digunakan di dalam survei geolistrik adalah teknik Vertical Electrical Sounding menggunakan konfigurasi Schlumberger. Teknik akuisisi ini dapat dilakukan dengan cara memvariasi jarak bentangan elektroda $\mathrm{C}_{1}$ terhadap $\mathrm{P}_{1}$, dan $\mathrm{C}_{2}$ terhadap $\mathrm{P}_{2}$ sebagaimana ditunjukkan pada Gambar 5. Mula-mula jarak bentangan antar masing-masing elektroda dibuat sama misalnya a. Lalu dilakukan pengukuran data yang meliputi kuat arus, beda potensial, dan jarak $1 / 2 \mathrm{AB}$ dan $1 / 2 \mathrm{MN}$. Pada saat pengukuran berikutnya jarak bentangan elektroda $\mathrm{C}_{1}$ diperlebar terhadap $\mathrm{P}_{1}$ dan $\mathrm{C}_{2}$ diperlebar terhadap $\mathrm{P}_{2}$, misalnya $2 a$. Demikian seterusnya sehingga pengukuran mencakup seluruh lintasan. Jarak bentangan antar elektroda potensial $\left(\mathrm{P}_{1}\right.$ dan $\left.\mathrm{P}_{2}\right)$ dapat diperlebar secara perlahan pada saat jarak bentangan antar elektroda arus $\left(\mathrm{C}_{1}\right.$ dan $\left.\mathrm{C}_{2}\right)$ sudah sedemikian jauh, asalkan terpenuhi syarat $\mathrm{AB} \geq 5 \mathrm{MN}$ [16]. Pemvariasian jarak antar elektroda secara gradual dilakukan untuk memperoleh data kedalaman dan jenis batuan bawah permukaan berdasarkan nilai resistivitas secara vertikal (vertical sounding). Semakin panjang jarak bentangan elektroda, maka informasi struktur dan jenis lapisan batuan bawah permukaan yang diperoleh juga semakin dalam [12].
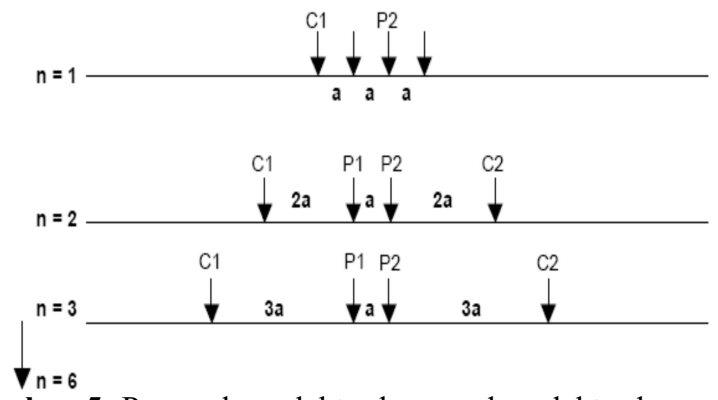

Gambar 5. Pergerakan elektroda arus dan elektroda potensial dalam survei geolistrik resistivitas konfigurasi Schlumberger.

Hasil akuisisi data resistivitas menggunakan teknik VES menghasilkan data resistivitas semu. Nilai resistivitas semu, selanjutnya diplot sehingga dapat diperoleh kurva logaritmik antara resistivitas semu masing-masing lapisan $\left(\rho_{a}\right)$ versus jarak bentangan $1 / 2 \mathrm{AB}$. Kurva logaritmik tersebut digunakan sebagai dasar dalam pemodelan, sehingga diperoleh kurva resistivitas sesungguhnya (true resistivity) versus jarak $1 / 2 \mathrm{AB}$ dan $\log$ resistivitas lapisan-lapisan batuan dilengkapi dengan kedalamannya. $\log$ resistivitas ini, selanjutnya diinterpretasi secara litologi sehingga diperoleh $\log$ litologi batuan bawah permukaan. Proses interpretasi dilakukan berdasarkan tabel resistivitas batuan dan informasi geologi daerah penelitian. 


\section{HASIL DAN PEMBAHASAN}

Akuisisi data resistivitas dilakukan pada bulan April 2017 di Desa Darmakradenan, Kecamatan Ajibarang, Kabupaten Banyumas, dengan peta lokasi ditunjukkan pada Gambar 5. Berdasarkan informasi geologi, Desa Darmakradenan terdiri atas formasi Tapak (Tpt) dan anggota batugamping formasi Tapak (Tptl) [17]. Formasi Tapak mendominasi bagian utara yang tersusun atas batupasir kasar berwarna kehijauan dan konglomerat, serta breksi andesit setempat. Pada bagian atas terdiri atas batupasir gampingan dan napal berwarna hijau yang mengandung kepingan moluska [17]. Adapun anggota batugamping dari Formasi Tapak terdapat di bagian selatan yang terdiri atas lensalensa batugamping yang tak berlapis, berwarna kelabu kekuningan [17]. Di desa Darmakradenan, cadangan batugamping terdapat di beberapa grumbul, antara lain di Pegawulan, Karangpucung, Angkruk dan Darma [9].

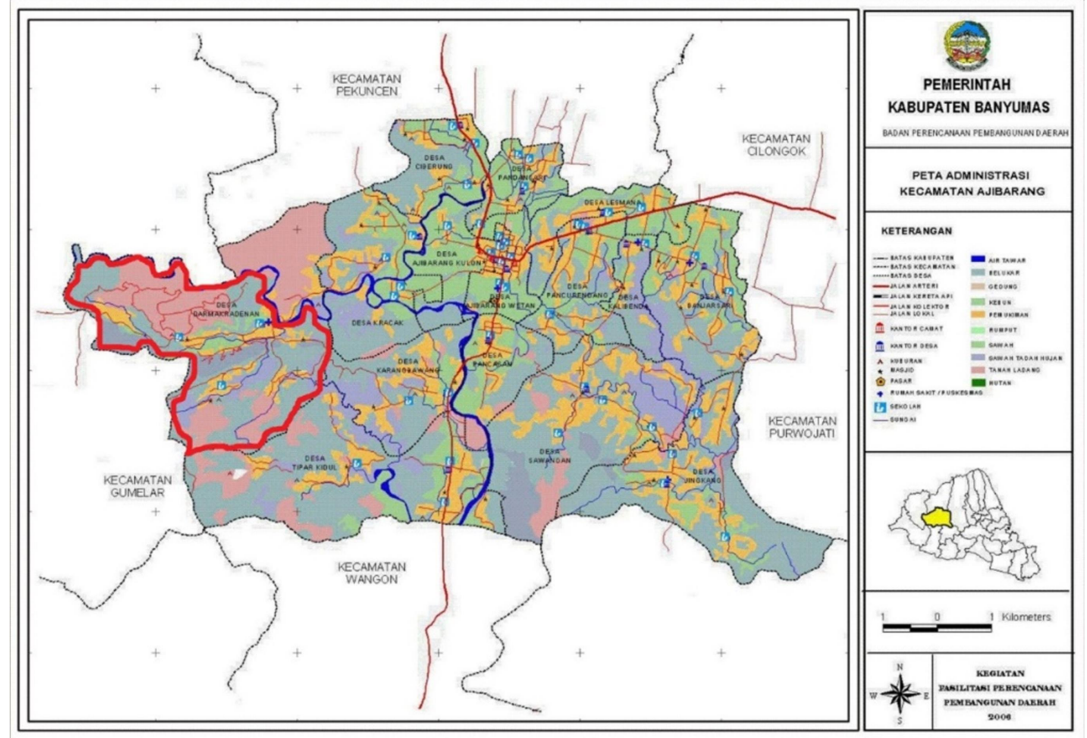

Gambar 5. Peta Kecamatan Ajibarang Kabupaten Banyumas; lokasi penelitian Desa Darmakradenan ditunjukkan di dalam garis merah [18].

Pengolahan data kuat arus $(I)$ dan beda potensial $(\Delta V)$ yang diperoleh dari akuisisi data resistivitas menggunakan alat Naniura Resistivitymeter dilakukan untuk mendapatkan nilai resistivitas semu setiap segmen pengukuran. Hasil yang diperoleh adalah kurva resistivitas semu versus jarak $1 / 2$ AB. Selanjutnya nilai resistivitas semu yang telah didapatkan ini dimodelkan secara inversi sehingga dapat diperoleh kurva resistivitas sesungguhnya (true resistivity) versus jarak $1 / 2 \mathrm{AB}$ dan $\log$ resistivitas seperti telah dijelaskan di bagian Metode Penelitian. $\quad$ og resistivitas ini merepresentasikan jenis-jenis lapisan batuan bawah permukaan berdasarkan nilai tahanan jenisnya. Hasil interpretasi terhadap $\log$ resistivitas telah menghasilkan log litologi batuan bawah permukaan, seperti dapat dilihat pada Gambar 7 hingga Gambar 11. Proses interpretasi mengacu pada informasi geologi setempat [17] dan tabel resistivitas batuan sebagaimana telah dijelaskan di bagian Tinjauan Pustaka.

Titik sounding pertama (L1) berada pada posisi geografis $7^{\circ} 25^{\prime} 21.31^{\prime \prime}$ LS dan $109^{\circ}$ 2'21.01" BT dan terletak di bawah bukit kapur. Titik sounding kedua (L2) berada pada posisi geografis $7^{\circ} 25^{\prime} 21.15^{\prime \prime L S}$ dan $109^{\circ} 2^{\prime} 22.20^{\prime \prime} \mathrm{BT}$ yang sejajar dengan titik L1. Titik sounding ketiga (L3) terletak relatif cukup jauh dari titik L2 pada posisi geografis $7^{\circ} 25^{\prime} 29.29^{\prime \prime} L S$ dan $109^{\circ} 2^{\prime} 19.70^{\prime \prime B T}$. Kawasan antara titik L2 dan L3 tidak dapat diambil datanya, sebab kondisi topografi yang curam dan tidak terdapat area untuk membentangkan kabel sejauh $200 \mathrm{~m}$ secara lurus dan datar. Titik sounding keempat (L4) terletak pada koordinat $7^{\circ} 25^{\prime} 30.79^{\prime \prime} L S$ dan $109^{\circ} 2^{\prime} 19.43$ "BT. Sedangkan titik sounding kelima (L5) terletak pada posisi geografis $7^{\circ} 25^{\prime} 31.59^{\prime \prime L S}$ dan $109^{\circ} \quad 2^{\prime 2} 20.66 " B T$. Selanjutnya hasil korelasi litologi lima titik sounding dapat dilihat pada Gambar 12. 


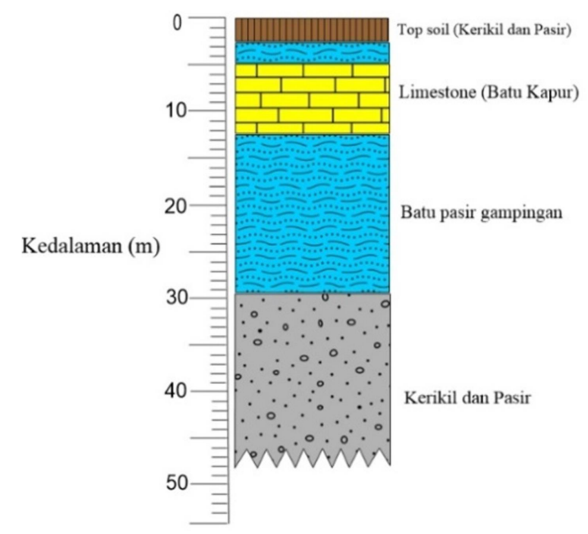

KETERANGAN

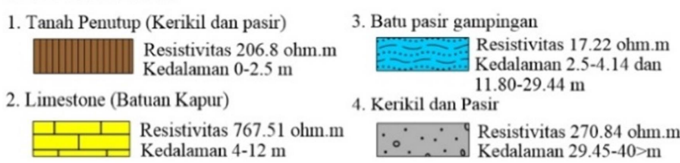

Gambar 7. Log litologi hasil pemodelan dan interpretasi data resistivitas pada titik sounding L1.

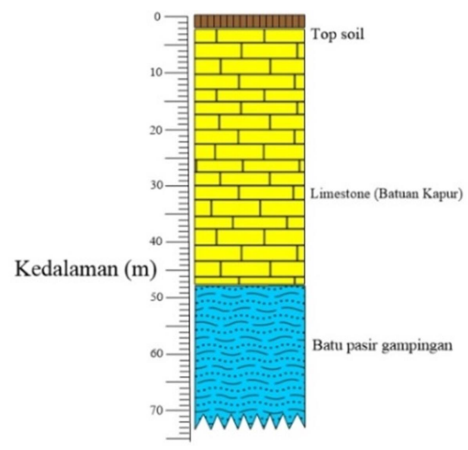

KETERANGAN

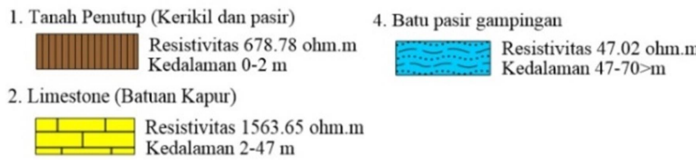

Gambar 8. Log litologi hasil pemodelan dan interpretasi data resistivitas pada titik sounding L2.

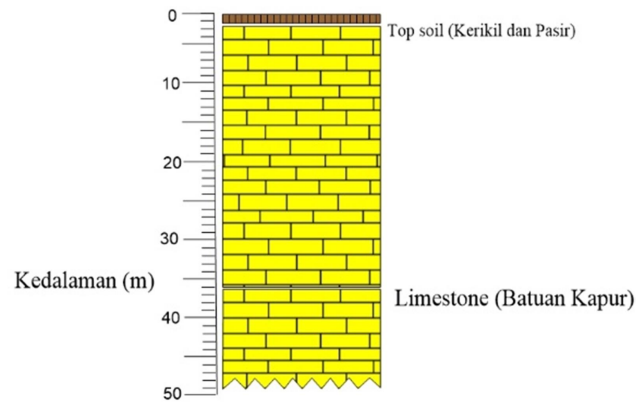

KETERANGAN

$$
\begin{aligned}
& \text { 1. Tanah Penutup (Kerikil dan pasir) } \\
& \text { 2. Limestone (Batuan Kapur) } \\
& \text { Kedalaman 0-1 m }
\end{aligned}
$$

Gambar 9. Log litologi hasil pemodelan dan interpretasi data resistivitas pada titik sounding L3.

Hasil pemodelan dan interpretasi pada titik sounding L1 menunjukkan keberadaan lapisan batupasir gampingan pada kedalaman 11.80 $29.44 \mathrm{~m}$ dengan nilai resistivitas sebesar 17.22 $\Omega \mathrm{m}$. Lapisan ini diestimasi sebagai lapisan akuifer air tanah. Lapisan ini diperkirakan menyambung dengan lapisan batupasir gampingan pada titik sounding L2, yang berada di kedalaman $>47 \mathrm{~m}$ dengan nilai resistivitas $47.02 \Omega \mathrm{m}$. Nilai resistivitas yang relatif tinggi dikaitkan dengan kemampatan batupasir gampingan pada lokasi L2. Pada titik sounding L3, L4, dan L5, lapisan akuifer tidak bisa dideteksi berdasarkan hasil pemodelan dan interpretasi data resistivitas. Ini diduga akibat panjang bentangan kabel arus hanya $200 \mathrm{~m}$, sehingga kedalaman maksimum yang terdeteksi hanya $100 \mathrm{~m}$ [12]. Di kawasan perbukitan karst sebenarnya sering dijumpai sungai bawah tanah yang menjadi pemasok ketersediaan air tanah yang sangat dibutuhkan di kawasan yang berada di atasnya. Umumnya kedalaman sungai-sungai tersebut sangat besar, sehingga sulit terdeteksi pada penelitian ini. Namun hal ini tidak menunjukkan bahwa di bawah perbukitan karst daerah penelitian ini terdapat sungai bawah tanah. Karst memiliki gaya permeabilitas yang relatif lamban dan didominasi oleh pori-pori mikro [18]. 


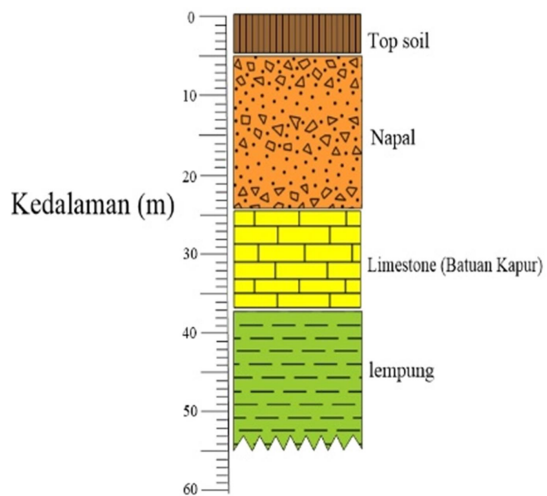

KETERANGAN

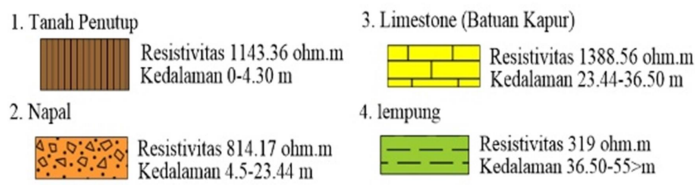

Gambar 10. Log litologi hasil pemodelan dan interpretasi data resistivitas pada titik sounding L4.

Hasil pemodelan dan interpretasi data resistivitas di titik sounding L1 hingga sounding L4 menunjukkan keberadaan lapisan batuan kapur (limestone). Batukapur ini sudah mulai terdeteksi pada kedalaman $1 \mathrm{~m}$ dengan nilai resistivitas yang berkisar $767.51-1563.65 \Omega \mathrm{m}$. Bahkan pada titik sounding L2 dan L3 batukapur cukup dominan. Oleh sebab itu daerah yang terletak di antara titik L2 dan L3 diestimasi didominasi oleh batukapur, meskipun di kawasan tersebut tidak terdapat titik sounding data [19]. Hal ini terlihat pada hasil korelasi $\log$ log litologi seperti ditunjukkan pada Gambar 12.
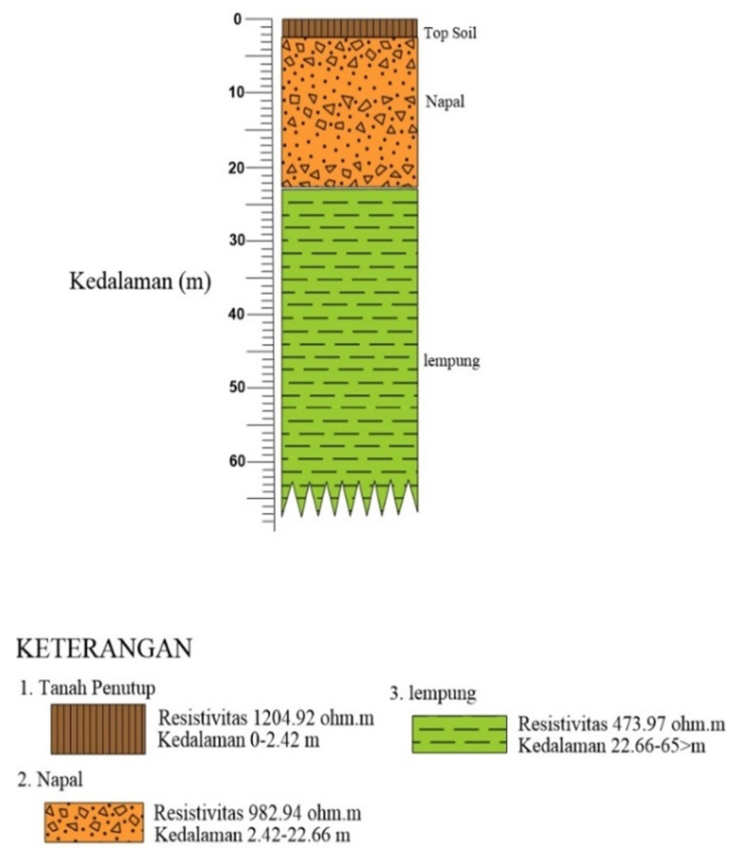

Gambar 11. Log litologi hasil pemodelan dan interpretasi data resistivitas pada titik sounding L5.

Selain batukapur yang menjadi sumberdaya alam utama di daerah penelitian, lapisan batuan lain yang diperoleh dari pemodelan dan interpretasi adalah kerikil dan pasir, napal, dan lempung. Kerikil dan pasir dijumpai pada titik sounding L1 dengan nilai resistivitas sebesar $270.84 \Omega \mathrm{m}$. Tingginya nilai resistivitas menunjukkan bahwa lapisan batuan relatif mampat dan padat, sehingga kandungan airnya sangat kecil. Selanjutnya batuan napal dan lempung ditemukan pada titik sounding L4 dan L5, dengan nilai resistivitas yang berkisar 814.17 - $982.94 \Omega \mathrm{m}$ untuk napal dan 319.00 $473.97 \Omega \mathrm{m}$ untuk lempung. Nilai resistivitas yang sangat tinggi tersebut mengindikasikan bahwa kedua jenis batuan dalam kondisi kering atau mampat sehingga tidak berpotensi mengandung air tanah secara signifikan [20].

Seluruh log litologi dan korelasinya menunjukkan bahwa potensi air tanah di daerah penelitian diperkirakan kecil. Log litologi yang menunjukkan keberadaan akuifer hanya ada di titik sounding L1 dan L2, namun nilai resistivitasnya cukup besar, berkisar 17,22 $47,02 \Omega \mathrm{m}$. Secara litologi, batuan ini diinterpretasi sebagai batupasir gampingan. Nilai resistivitas yang besar mengindikasikan bahwa kandungan air di dalam lapisan batuan tersebut umumnya kecil [20]. Kemungkinan lapisan akuifer pada dua titik sounding tersebut merupakan jalur bagi air permukaan untuk mengalir menuju ke akuifer dalam atau sungai di 
bawah perbukitan karst yang biasanya sangat dalam. Hasil-hasil pemodelan data resistivitas dengan panjang bentangan $200 \mathrm{~m}$ sebagaimana penelitian ini, secara teoritis hanya dapat menjangkau kedalaman maksimum $100 \mathrm{~m}$ [12]. Hasil pemodelan dan interpretasi pada penelitian ini tidak menemukan keberadaan akuifer dalam dan/atau sungai bawah tanah. Oleh sebab itu sumber-sumber air tanah yang potensial di daerah penelitian tidak ditemukan berdasarkan hasil eksplorasi menggunakan metode geolistrik resistivitas dengan panjang bentangan elektroda arus sebesar $200 \mathrm{~m}$.

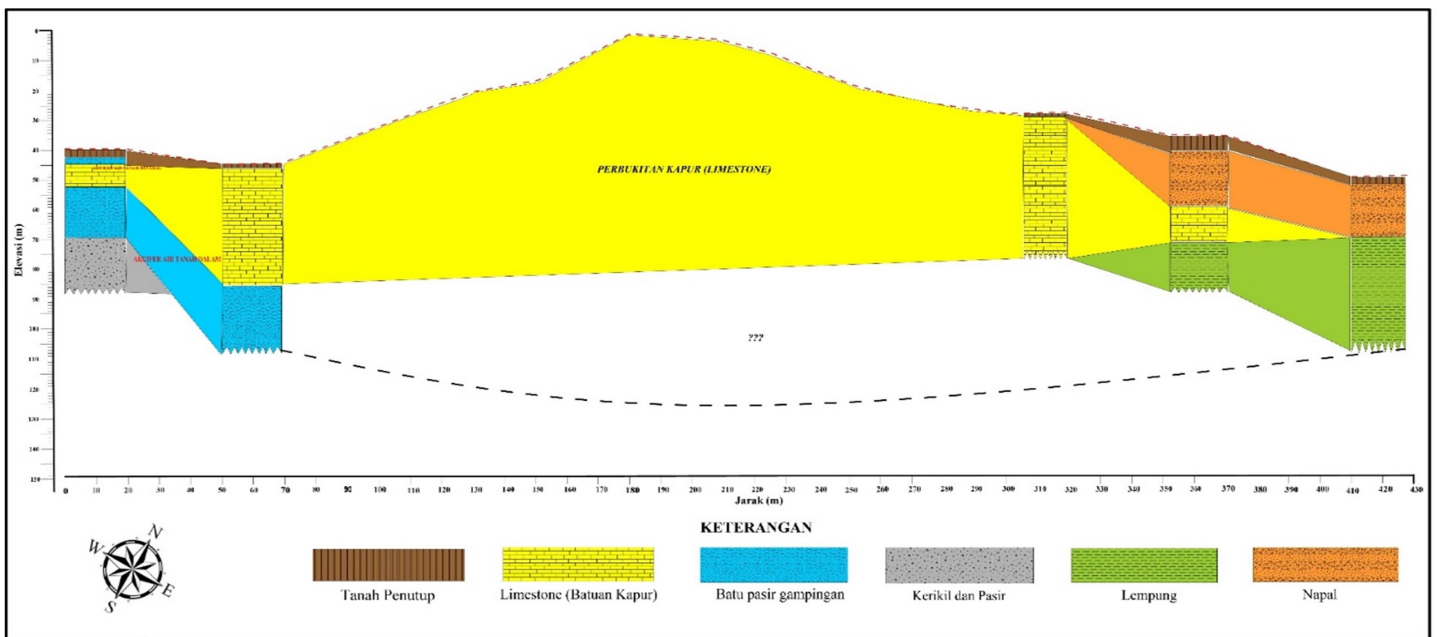

Gambar 12. Penampang litologi batuan bawah permukaan hasil korelasi antar log litologi pada masing-masing titik sounding.

\section{KESIMPULAN}

Berdasarkan hasil penelitian tentang eksplorasi sumber air tanah bawah perbukitan kapur (karst) menggunakan metode geolistrik resistivitas dengan konfigurasi Schlumberger yang dilaksanakan di Desa Darmakradenan Kecamatan Ajibarang Kabupaten Banyumas dapat disimpulkan:

1. Struktur batuan bawah permukaan di daerah penelitian terdiri atas enam satuan litologi, yaitu: tanah penutup (206.80 1204.93 $\Omega \mathrm{m})$, batukapur (767.51 - 1563.65 $\Omega \mathrm{m})$, batupasir gampingan (17.22 - 47.02 $\Omega \mathrm{m})$, pasir dan kerikil $(270.84 \Omega \mathrm{m})$, napal (814.17 - $982.94 \Omega \mathrm{m})$, dan lempung $(319.00-473.97 \Omega m)$.

2. Lapisan yang diduga mengandung air hanya ditemukan pada titik sounding L1 dan L2 pada lapisan batupasir gampingan dengan nilai resistivitas $17.22-47.02 \Omega \mathrm{m}$. Namun lapisan batuan ini diperkirakan bukan akuifer yang potensial, dan diestimasi merupakan jalur bagi air permukaan untuk mengalir menuju ke akuifer dalam atau sungai bawah perbukitan karst.

3. Eksplorasi menggunakan metode geolistrik resistivitas dengan panjang bentangan elektroda arus $200 \mathrm{~m}$ tidak menemukan keberadaan sumber-sumber air tanah yang potensial di daerah penelitian.

\section{UCAPAN TERIMA KASIH}

Terima kasih disampaikan kepada Kepala Laboratorium Elektronika, Instrumentasi, dan Geofisika Fakultas MIPA, Universitas Jenderal Soedirman atas peralatan Resistivity-meter merk NANIURA yang digunakan dalam akusisi data. Terimakasih juga disampaikan kepada tim survei geolistrik yang telah bersusah payah dan bersinergi dalam melakukan akuisisi data resistivitas di lapangan.

\section{DAFTAR PUSTAKA}

[1] H. Bouwer, Groundwater Hydrology. McGraw-Hill Book Company, New York, 1978.

[2] I. I. S. Purnama, "Ketersediaan dan Kualitas Airtanah pada Akuifer Tidak Tertekan di Kecamatan Jawilan dan Kopo Kabupaten Serang", Majalah Geografi Indonesia 33(1) (2019) 16-25.

[3] M.R.S.S. Kumar,G. Swathi, "Vertical Electrical Sounding (VES) for Subsurface Geophysical Investigation Inkanigiri Area, 
Prakasam District, Andhra Pradesh, India", Advances in Applied Science Research 5(5) (2014) 82-86.

[4] E.O. Joshua, O.O. Odeyemi, O.O. Fawehinmi, "Geoelectric Investigation of the Groundwater Potential of Moniya Area", Ibadan. Journal of Geology and Mining Research 3(3) (2011) 54-62.

[5] A.S. Wijaya, "Aplikasi Metode Geolistrik Resistivitas Konfigurasi Wenner untuk Menentukan Struktur Tanah di Halaman Belakang SCC ITS Surabaya", Jurnal Fisika Indonesia 19(55) (2015) 1-5.

[6] P. Lepong, Supriyanto, S. Wahyuningsih, Hardiyanto, "Appli-cation of Multi-Array Electrical Resistivity Tomography in PT. Bukit Baiduri Energi Coal Mining-East Kalimantan", Indonesian Mining Journal 21(1) (2018) 1-7.

[7] M.A. Khalil , F.A.M. Santos, "2D and 3D Resistivity Inversion of Schlumberger Vertical Electrical Soundings in Wadi El Natrun, Egypt: A Case Study", Journal of Applied Geophysics 89 (2013) 116-124.

[8] Tempo.co, Spiderman di atas Bukit Kapur. Edisi: Senin, 24 September 2012. Sumber: https://nasional.tempo.co/read/431411/spiderman-di-atas-bukit-kapur, Diakses: 3 Feb 2021.

[9] R. Hutamadi, Mulyana. "Evaluasi Sumberdaya dan Cadangan Bahan Galian untuk Pertambangan Skala Kecil Daerah Kabupaten Banyumas Provinsi Jawa Tengah", Badan Geologi. Kementerian ESDM, Jakarta, 2011.

[10] A.A. Aning, N. Sackey, I.S. Jakalia, O. Sedoawu, E. H. Tetteh, G. Hinson, R. Akorlie, D. Appiah, E. Quaye, "Electrical Resistivity as a Geophysical Mapping Tool; A Case Study of the New Art Department Knust-Ghana", International Journal of Scientific and Research Publication 4(1) (2014) 1-7.

[11] Sehah, A. N.Aziz, "Pendugaan Kedalaman Air Tanah Menggunakan Metode Geolistrik Konfigurasi Schlumberger di Desa Bojongsari Kecamatan Alian Kabupaten Kebumen", Jurnal Neutrino 8(2) (2016) 41-49.
[12] W. M. Telford, L. P. Geldart, R. E. Sheriff, Applied Geophysics, Cambridge University, New York. USA, 1990.

[13] AGI. Schlumberger Array: Electrical Resistivity Methods, Part2. Sumber: https://www.agiusa.com/schlumbergerarray. Diakses: 3 Feb 2021.

[14] M.H. Syahruddin, "Persamaan Aliran Air dalam Media Berpori sebagai Aliran Airtanah (Groundwater)", Simposium Fisika Nasional 2014 (SFN XXVII). Denpasar-Bali. 16-17 Oktober 2014.

[15] H. Hendrayana, Hidrogeologi Mata Air. Lecture note. Teknik Geologi, Fakultas Teknik, Universitas Gadjah Mada (UGM). Yogyakarta, 2013.

[16] Lutan, A, Metode Pengukuran Tahanan Jenis Bawah Permukaan Tanah. DikLat Geofisika Eksplorasi Terbatas, Lembaga Físika Nasional, LIPI, Jakarta, 1981.

[17] M. Djuri, H. Samodra, S. Gafoer, Peta Geologi Lembar Purwokerto - Tegal Jawa; Skala 1:100,000. Pusat Penelitian dan Pengembangan Geologi (P3G), Bandung, 1996.

[18] S. Sarminah, Indirwan, "Kajian Laju Infiltrasi pada Beberapa Tutupan Lahan di Kawasan Karst Sangkulirang-Mangkalihat Kabupaten Kutai Timur", Jurnal AGRIFOR 16(2) (2017) 301-310.

[19] R.F. Aziz, “Arahan Teknik Reklamasi Tambang Batugamping Berdasarkan Tingkat Kerusakan Lahan di Desa Darmakrade-nan, Kec. Ajibarang, Kab. Banyumas Jawa Tengah", Skripsi. Program Studi Teknik Lingkungan, FTM, UPN "Veteran" Yogyakarta, Desember, 2017.

[20] K.M. Arsyad, Modul Geologi dan Geoteknik: Pelatihan Perencanaan Embung. Pusat Pendidikan dan Pelatihan Sumberdaya Air dan Konstruksi. Badan Pengembangan Sumberdaya Manusia. Kementerian Pekerjaan Umum dan Perumahan Rakyat, Bandung, 2017. 